\title{
Effect of Melatonin on some Inflammatory Markers in L-arginine Induced acute Pancreatitis in Rats
}

\author{
Hala E. Hamouda*, Ahmed A. Abd-Allah*, Ghada A. Abd El Alem*, \\ Omnia S. El-Deeb* Kareema I. El-Desoky** \\ Departments, of Medical Biochemistry* and Pathology** \\ Faculty of Medicine, Tanta University
}

\begin{abstract}
Objective: Acute pancreatitis is an inflammatory disease of the pancreas resulting in significant morbidity and mortality, due to distant organ failure. Melatonin exerts complex physiological and pharmacological effects on multiple systems and organs. Aim of the study: The present study was designed to investigate the effects of melatonin pre- and post-treatment with L-arginine (L-Arg.) on some inflammatory markers in acute pancreatitis in rats. Materials and methods: The present study was carried out on 75 white albino rats which were randomly classified into five equal groups; group I (control group); group II (L-arginine injected group); group III (melatonin pre-treatment with L-arginine); group IV (melatonin post-treatment with L-arginine) and group $\mathbf{V}$ (melatonin injected group). All groups were subjected to measurements of serum amylase and lipase activities; total antioxidant capacity (TAC) levels, serum and tissue TNF a levels; MPO and PON1 enzymes activities, in addition to histopathological examination of all pancreatic specimens. Results: L-arginine injected group showed severe necrotizing pancreatitis confirmed by histopathological changes and significant elevations in serum amylase and lipase activities relative to the control values. Also, significant increase of serum TAC, serum and tissue TNF- $\alpha$ levels and MPO enzyme activity and significant decrease of PON-1 enzyme activity were detected in L-arginine injected group as compared to control group. In melatonin injected groups, either pre- or post- treatment with L-arginine, serum amylase and lipase activities and both serum and tissue TNF- $\alpha$ levels, MPO activity were significantly decreased in both groups with significantly lower levels in rats given melatonin pre- treatment with L-arginine. Also, significant increase of both serum and tissue PON-1 were found in both groups. Conclusion: These data might confirm the protective effect of melatonin as an antioxidant in acute pancreatitis.

Key wards: Acute pancreatitis (AP), tissue tumor necrosis $\alpha\left(\begin{array}{lll}T N F & \alpha\end{array}\right)$, myeloperoxidase (MPO), paraoxonase-1 (PON-1)
\end{abstract}

\section{INTRODUCTION}

Acute pancreatitis is an inflammatory disease characterized by increasing incidence and associated with high morbidity and mortality ${ }^{(\mathbf{1})}$.
The most important predictor of mortality is the development of persistent multiple organ failure ${ }^{(2)}$. The mechanisms involved in triggering distant organ inflammation are unclear, however, in addition to 
the release of activated hydrolytic enzymes, different pathways have been reported, including cytokines ${ }^{(3)}$, oxygen-derived free radicals $^{(4)}$, or activated complement ${ }^{(5)}$.

Cytokines are a family of low molecular weight proteins which are not constitutively expressed in normal tissues and up-regulation is usually initiated following external stimuli such as injury or stress in various cell types: On a functional basis cytokines can be classified into two groups; the pro- and the anti-inflammatory cytokines $^{(3)}$. Tumor necrosis factor $\alpha$ $(\mathrm{TNF}-\alpha)$ is a pro-inflammatory cytokine involved in systemic inflammation and stimulate acute phase reaction. It exerts hostdamaging effects in different autoimmune and inflammatory diseases. Dysregulation of TNF- $\alpha$ production has been implicated in a variety of human diseases, as well as cancer $^{(6)}$.

Neutrophils play a key role in tissue destructive conditions in various inflammatory diseases. Leukocyte activation, including neutrophils, is an important link in the pathogenesis of acute pancreatitis (AP) and associated lung injury ${ }^{(7)}$. When neutrophils become activated during phagocytosis, they undergo a process referred to as a respiratory burst. This respiratory burst causes production of superoxide, hydrogen peroxide, and other reactive oxygen species (ROS), which are all toxic to microbes $^{(7)}$. Upon stimulation, neutrophils assemble and activate nicotinamide adenine dinucleotide phosphate (NADP) dependent oxidase, thus generating hydrogen peroxide, and degranulate, thereby releasing the proteins of azurophilic granules into the phagolysosome. Reactive oxygen radical formation and the liberation of proteolytic enzymes from the neutrophil granules are the two mechanisms of the damaging action of neutrophils ${ }^{(8)}$.

One of the enzymes contained in azurophilic granules is myeloperoxidase (MPO) which in combination with halides and hydrogen peroxide is toxic for many cells, such as tumor cells, erythrocytes, platelets, leukocytes, and microorganisms ${ }^{(9)}$.

The antioxidant status of tissues can be described by the analysis of single components in the defense systems against ROS, as well as by the determination of total antioxidant capacity (TAC). In contrary, the TAC measurement does not represent the sum of activities of antioxidants; it could be used for clinical diagnosis, as it is an easy and less time-consuming procedure ${ }^{(10)}$.

Paraoxonase-1 (PON1) is expressed in the liver, released to the blood and is associated with the highdensity lipoprotein (HDL) particle ${ }^{(11)}$. PON-2 is not present in blood, but is expressed widely in a number of tissues, including the liver, lungs, brain and heart ${ }^{(12)}$. Of the paraoxonase family, PON-1 is the most investigated and best understood member ${ }^{(11)}$.

Melatonin is a hormone secreted by the pineal gland in the brain. It is a potent scavenger of ROS and highly effective protector of various tissues against the effects of $\operatorname{ROS}^{(13)}$. Melatonin is not only a non-enzymatic scavenger, but also an inducer of antioxidative enzymes such as superoxide 
dismutase (SOD), catalase (CAT), and glutathione peroxidase (GPx) ${ }^{(14) \text {. }}$

The present study was designed to investigate the effects of melatonin pre- and post-treatment with Larginine (L-Arg.) on some inflammatory markers in acute pancreatitis in rats.

\section{MATERIALS \& METHODS}

The present study was carried out on 75 white albino rats, their weight ranged 150-200 g.. During the study the animals were kept in wire mesh cages and were fed standard rat chew and allowed free access to water. They were kept under constant environmental conditions $\left(25^{\circ} \mathrm{C}\right.$ and 12 hours dark/light cycle). The animals were randomly classified into five equal groups.

1. Group I (control group): Rats received I.P injection of physiological saline in a dose of 3.2 $\mathrm{ml} / \mathrm{kg}$ body weight.

2. Group II: In which acute pancreatitis was induced by I.P injection of $3.2 \mathrm{~g} / \mathrm{kg}$ body weight Larginine twice at an interval of one hour.

3. Group III: Rats were subjected to preliminary I.P injection of a single dose of melatonin $(50 \mathrm{mg} / \mathrm{kg}$ body weight), 30 minutes prior to induction of pancreatitis with Larginine.

4. Group IV: Rats received the same dose of melatonin one hour after the second injection of L-Arginine.

5. Group V: Rats received I.P injection of a single dose of melatonin ( $50 \mathrm{mg} / \mathrm{kg}$ body weight).

Chemicals used in the experiment including melatonin, L-arginine and paraoxon were obtained from Sigma chemical Co. St., Louis, MO, (USA). The doses of melatonin were chosen on the basis of previous studies ${ }^{(15)}$. All experiments were carried out according to the guidelines of the Ethical Committee of Tanta University, Faculty of Medicine.

- Sample collection:

By the end of the experimental period (24 hours), all rats were sacrificed and blood samples were collected. Sera were separated and stored in aliquots at $-70{ }^{\circ} \mathrm{C}$ till used. Then, the abdomen and the thorax were opened and the pancreases were dissected, washed three times in ice cold saline and blotted individually on ash-free filter paper. One piece was kept into $10 \%$ formalin solution and fixed for histopathological examination, and the remaining pieces were stored at $-70{ }^{\circ} \mathrm{C}$ till used for preparation of tissue homogenates. Specimens were weighed and homogenized with a potterElvenhjem tissue homogenizer (20-30 up and-down strokes). One part was homogenized in $1.15 \% \mathrm{KCl}$ for estimation of myeloperoxidase activity and tumor necrosis factor $\alpha$ and the second one in Tris- $\mathrm{HCl}$ $100 \mathrm{mM}, \mathrm{pH} 8$ for estimation of PON1 activity and protein content. Tissue homogenate was centrifuged at 7,700 $\mathrm{x} g$ for 30 minutes at $4^{\circ} \mathrm{C}$, and the resultant supernatant was assayed for the different estimations.

All groups were subjected to measurements of the following;

1. Spectrophotometric determination of serum amylase ${ }^{(\mathbf{1 6})}$ and lipase enzymes activities ${ }^{(\mathbf{1 7})}$.

2. Spectrophotometric determination of serum total antioxidant capacity 
using a commercial kit (Biodiagnostic Company Egypt) ${ }^{(\mathbf{1 8})}$.

3. Estimation of serum and tissue tumor necrosis factor $\alpha$ levels: By using RayBiotech, Rat TNF-Alpha ELISA Kit ${ }^{(19)}$

4. Spectrophotometric determination of serum and tissues myeloperoxidase enzyme activity ${ }^{(20)}$.

5. Determination of serum and tissue PON1 enzyme activity ${ }^{(21)}$

6. Estimation of protein content was performed for pancreatic tissue homogenates according to Lowry et al. $(1951)^{\mathbf{( 2 2})}$

7. Histopathological examination of formalin fixed pancreatic specimens.

\section{Statistics:}

Statistical data and analyses used in the present study were conducted, using range, the mean, standard deviation, analysis of variance [ANOVA] test followed by Tukey's post hoc test and linear correlation coefficient(r). $\mathrm{P}<0.05$ was considered significant.

\section{RESULTS}

Tables 1 and 2 illustrate the statistical comparison between all studied parameters in both serum and pancreatic tissues in the studied groups. They showed significant increase of both serum amylase and lipase activities in L-arginine injected group (group II), when compared to the other groups $(\mathrm{P}<0.001)$. Their activities showed significant decrease in melatonin injected groups both preand post- treatment with L- arginine (groups III and group IV) ( $\mathrm{P}<0.001)$, with the lowest levels in group III. There was no significant difference between the control group (group I) and melatonin injected group (group V) $(\mathrm{P}>0.05)$

Serum and tissue TNF- $\alpha$ levels and MPO enzyme activities were significantly increased in L-arginine injected group (group II) as compared to the other groups $(\mathrm{P}<0.001)$. Significant decrease in their values were detected in melatonin injected groups (groups III and group IV), with the lowest values in group III ( $P$ $<0.001)$. There was no significant difference between the control group (group I) and melatonin injected group (group $\mathrm{V})(\mathrm{P}>0.05)$.

Serum total antioxidant capacity level was significantly increased in L-arginine injected group (group II) when compared to the other groups $(\mathrm{P}<0.001)$. Significant increase of its level was also found in group III as compared to group I and group IV, with non significant difference between it and L-arginine injected group (group II) $(\mathrm{P}>0.05)$.

Serum and tissue PON1 enzyme activities showed significant decrease in L-arginine injected group (group II) when compared to the other groups ( $\mathrm{P}$ $<0.001)$. There was significant increase in their activities in both melatonin injected groups as compared to group I and group II (P $<0.001$ ), with non significant difference between them $(\mathrm{P}>0.05)$. There was significant increase in their activity in melatonin injected group (group V) when compared to the control (P-value $<0.001$ ).

Correlation studies showed significant positive correlation between serum TNF- $\alpha$ and serum amylase $(\mathrm{r}=0.97, \quad \mathrm{P}<0.001)$, lipase $(\mathrm{r}=0.929, \mathrm{P}<0.001)$, serum TAC $(\mathrm{r}$ 
$=0.74, \quad \mathrm{P}<0.001)$, and serum $\mathrm{MPO}$ activity $\quad(\mathrm{r}=0.863, \quad \mathrm{P}<0.001)$. Significant negative correlation was found between serum TNF- $\alpha$ and serum PON1 activity $(r=-0.85$, $\mathrm{P}<0.001$ ) which showed significant negative correlation with serum levels of amylase $(\mathrm{r}=-0.863, \mathrm{P}<0.001)$, lipase $(\mathrm{r}=-0.803, \quad \mathrm{P}<0.001), \quad \mathrm{TAC} \quad(\mathrm{r}=-$ $0.591, \mathrm{P}<0.001)$, and serum MPO activity $(\mathrm{r}=-0.729, \mathrm{P}<0.001)$. MPO enzyme activities showed significant positive correlation with serum amylase $(\mathrm{r}=0.858, \& \mathrm{P}<0.001)$, lipase $(\mathrm{r}=0.882, \mathrm{P}<0.001)$ and serum $\mathrm{TAC}$ $(\mathrm{r}=0.793, \quad \mathrm{P}<0.001) . \quad$ Significant positive correlation between TAC and serum amylase $(\mathrm{r}=0.79, \mathrm{P}<0.001)$, and lipase $(\mathrm{r}=0.762, \mathrm{P}<0.001)$. Also, there was significant positive correlation between serum amylase and lipase activities ( $\mathrm{r}=0.942$, $\mathrm{P}<0.001$ ), table 3 .

Significant negative correlation between tissue TNF- $\boldsymbol{\alpha}$ levels and tissue PON-1 activities $(r=-0.914$, $\mathrm{P}<0.001$ ) with significant positive correlation between it and tissue MPO activities $\quad(\mathrm{r}=0.837, \mathrm{P}-<0.001)$. There was significant negative correlation between tissue PON-1activity and tissue MPO activity ( $\mathrm{r}=-0.754, \mathrm{P}$ $<0.001$ ), table 4 .

Significant positive correlation was found between serum and tissue TNF- $\alpha$ levels $(\mathrm{r}=0.947, \mathrm{P}<0.001)$ and between serum and tissue MPO activity $\quad(\mathrm{r}=0.904, \quad \mathrm{P}<0.001$. Also between serum and tissue PON-1 activity $(r=0.813 \& \mathrm{P}<0.001)$ table 5.

Histopathological results showed no changes in the gross and histological appearance of the pancreases regarding pancreatic acini and normal pancreatic islets with normal vasculature from control group, as shown in Fig 1. However, sections of the pancreas of L-arginine injected group (group II), showed severe inflammatory cellular infiltrate formed of lymphocytes and plasma cells associated with severe edema and focal necrotic acinar cells with hyperemia (vascular dilatation and congestion) (Fig 2). In melatonin injected group before L-arginine injection (group III) sections of the pancreas showed mild edema with minimal cellular infiltration mainly lymphocytic population with few plasma cells and normal pancreatic acini (Fig 3). Sections of the pancreas of melatonin injected group after Larginine injection (group IV) showed moderate to severe edema and severe vascular dilatation with mild lymphocytic infiltration (Fig 4). Section of the pancreas in melatonin injected group (group V) showed normal pancreatic architecture regarding acini, islets and vasculature (Fig 5). 
Table 1: Comparison between the studied serum parameters in all the studied groups.

\begin{tabular}{|c|c|c|c|c|c|c|c|}
\hline & \multirow{2}{*}{ Group I } & \multirow{2}{*}{ Group II } & \multirow{2}{*}{$\begin{array}{c}\text { Group } \\
\text { III }\end{array}$} & \multirow{2}{*}{$\begin{array}{l}\text { Group } \\
\text { IV }\end{array}$} & \multirow{2}{*}{ Group V } & \multicolumn{2}{|c|}{ ANOVA } \\
\hline & & & & & & $\mathbf{F}$ & P. value \\
\hline $\begin{array}{c}\text { Serum amylase } \\
(\mathrm{U} / \mathrm{L})\end{array}$ & $\begin{array}{r}63.33 \\
+28.61 \\
\end{array}$ & $\begin{array}{r}23973.33 \\
+2673.94 \\
\end{array}$ & $\begin{array}{r}13073.73 \\
+1881.36 \\
\end{array}$ & $\begin{array}{r}17427.80 \\
+1164.51 \\
\end{array}$ & $\begin{array}{r}71.33 \\
+24.83 \\
\end{array}$ & 704.85 & $<0.001 *$ \\
\hline $\begin{array}{c}\text { Serum lipase } \\
(\mathrm{U} / \mathrm{L})\end{array}$ & $\begin{array}{c}37.467 \\
+15.684 \\
\end{array}$ & $\begin{array}{r}1341.33 \\
+338.75 \\
\end{array}$ & $\begin{array}{c}750.60 \\
+121.44 \\
\end{array}$ & $\begin{array}{r}1090 \\
+82.59 \\
\end{array}$ & $\begin{array}{c}38.06 \\
+18.23 \\
\end{array}$ & 196.031 & $<0.001^{*}$ \\
\hline $\begin{array}{l}\text { Serum TNF } \alpha \\
\quad(\mathrm{pg} / \mathrm{ml})\end{array}$ & $\begin{array}{c}7.053 \\
+1.303\end{array}$ & $\begin{array}{r}192.31 \\
+25.06\end{array}$ & $\begin{array}{c}113.31 \\
+14.312\end{array}$ & $\begin{array}{r}143.98 \\
+14.16\end{array}$ & $\begin{array}{c}4.80 \\
+0.80\end{array}$ & 507.447 & $<0.001 *$ \\
\hline $\begin{array}{c}\text { Serum MPO } \\
(\mathrm{U} / \mathrm{ml})\end{array}$ & $\begin{array}{c}2.773 \\
+0.779 \\
\end{array}$ & $\begin{array}{r}13.360 \\
+2.634 \\
\end{array}$ & $\begin{array}{c}5.380 \\
+0.814 \\
\end{array}$ & $\begin{array}{r}11.380 \\
+1.611 \\
\end{array}$ & $\begin{array}{r}2.420 \\
+0.704 \\
\end{array}$ & 167.724 & $<0.001^{*}$ \\
\hline $\begin{array}{l}\text { Serum TAC } \\
(\mathrm{mM} / \mathrm{l})\end{array}$ & $\begin{array}{r}410.06 \\
+75.06\end{array}$ & $\begin{array}{r}1126.66 \\
+258.31\end{array}$ & $\begin{array}{r}1082.86 \\
+127.32\end{array}$ & $\begin{array}{r}703.93 \\
+90.12\end{array}$ & $\begin{array}{c}556 \\
+65.64\end{array}$ & 75.114 & $<0.001 *$ \\
\hline $\begin{array}{c}\text { Serum PON } 1 \\
\text { enzyme activity } \\
(\mathrm{U} / \mathrm{ml})\end{array}$ & $\begin{array}{l}176.06 \\
+17.84\end{array}$ & $\begin{array}{l}78.933 \\
+11.58\end{array}$ & $\begin{array}{l}153.13 \\
+14.26\end{array}$ & $\begin{array}{r}163.200 \\
+16.187\end{array}$ & $\begin{array}{r}217.667 \\
+29.645\end{array}$ & 106.311 & $<0.001 *$ \\
\hline
\end{tabular}

Group I: Control group $(\mathrm{no}=15)$.

Group II: L-arginine injected group (no=15).

Group III: Melatonin injection pre-treatment with L-arginine (no=15).

Group IV: Melatonin injection post-treatment with L-arginine (no=15).

Group V: Melatonin injected group (no=15).

Table 2: Comparison between all tissue studied parameters in the studied groups.

\begin{tabular}{|c|c|c|c|c|c|c|c|}
\hline & \multirow{2}{*}{ Group I } & \multirow{2}{*}{ Group II } & \multirow{2}{*}{ Group III } & \multirow{2}{*}{ Group IV } & \multirow{2}{*}{ Group V } & \multicolumn{2}{|c|}{ ANOVA } \\
\hline & & & & & & $\mathbf{F}$ & P. value \\
\hline $\begin{array}{l}\text { Tissue TNF } \alpha \\
\text { ( pg/mg protein) }\end{array}$ & $\begin{array}{r}25.047 \\
+6.072\end{array}$ & $\begin{array}{c}260.493 \\
+29.547\end{array}$ & $\begin{array}{l}133.753 \\
+14.003\end{array}$ & $\begin{array}{l}174.227 \\
+14.488\end{array}$ & $\begin{array}{l}16.047 \\
+4.039\end{array}$ & 600.601 & $<0.001 *$ \\
\hline $\begin{array}{c}\text { Tissue MPO } \\
\text { (U/mg protein) }\end{array}$ & $\begin{array}{r}4.387 \\
+0.736\end{array}$ & $\begin{array}{l}14.693 \\
+2.735\end{array}$ & $\begin{array}{c}6.880 \\
+0.880\end{array}$ & $\begin{array}{r}13.027 \\
+1.372\end{array}$ & $\begin{array}{c}4.587 \\
+0.690\end{array}$ & 157.112 & $<0.001^{*}$ \\
\hline $\begin{array}{c}\text { Tissue PON1 } \\
\text { enzyme activity } \\
\text { (U/mg protein) }\end{array}$ & $\begin{array}{r}345.733 \\
+84.380\end{array}$ & $\begin{array}{r}145.533 \\
+34.961\end{array}$ & $\begin{array}{r}259.600 \\
+27.841\end{array}$ & $\begin{array}{r}252.533 \\
+28.685\end{array}$ & $\begin{array}{r}551.600 \\
+59.202\end{array}$ & 129.046 & $<0.001 *$ \\
\hline
\end{tabular}

Group I: Control group (no=15).

Group II: L-arginine injected group $(\mathrm{no}=15)$.

Group III: Melatonin injection pre-treatment with L-arginine (no=15).

Group IV: Melatonin injection post-treatment with L-arginine $(\mathrm{no}=15)$.

Group V: Melatonin injected group $(\mathrm{no}=15)$. 
Table 3: Correlation between all studied parameters in the serum.

\begin{tabular}{|c|c|c|c|c|c|c|}
\hline & & $\begin{array}{c}\text { Serum } \\
\text { TNF- } \alpha \\
(\mathrm{pg} / \mathrm{ml})\end{array}$ & $\begin{array}{l}\text { Serum } \\
\text { PON-I } \\
(\mathrm{U} / \mathrm{ml}) \\
\end{array}$ & $\begin{array}{c}\text { Serum } \\
\text { MPO } \\
(\mathrm{U} / \mathrm{ml}) \\
\end{array}$ & $\begin{array}{c}\text { Serum } \\
\text { TAC } \\
(\mathrm{mM} / \mathbf{l}) \\
\end{array}$ & $\begin{array}{c}\text { Lipase } \\
\text { (U/L) }\end{array}$ \\
\hline \multirow{2}{*}{$\begin{array}{l}\text { Serum PON-1 } \\
(\mathrm{U} / \mathrm{ml})\end{array}$} & $\mathbf{r}$ & -0.85 & & & & \\
\hline & P-value & $<0.001^{*}$ & & & & \\
\hline \multirow{2}{*}{$\begin{array}{l}\text { Serum MPO } \\
(\mathrm{U} / \mathrm{ml})\end{array}$} & $\mathbf{r}$ & 0.863 & -0.729 & & & \\
\hline & P-value & $<0.001^{*}$ & $<0.001^{*}$ & & & \\
\hline \multirow{2}{*}{$\begin{array}{l}\text { Serum TAC } \\
(\mathrm{mM} / \mathrm{l})\end{array}$} & $\mathbf{r}$ & 0.74 & -0.591 & 0.793 & & \\
\hline & P-value & $<0.001^{*}$ & $<0.001^{*}$ & $<0.001^{*}$ & & \\
\hline \multirow{2}{*}{ Lipase (U/L) } & $\mathbf{r}$ & 0.929 & -0.803 & 0.882 & 0.762 & \\
\hline & P-value & $<0.001^{*}$ & $<0.001^{*}$ & $<0.001^{*}$ & $<0.001 *$ & \\
\hline \multirow{2}{*}{ Amylase (U/L) } & $\mathbf{r}$ & 0.97 & -0.863 & 0.858 & 0.79 & 0.942 \\
\hline & P-value & $<0.001^{*}$ & $<0.001^{*}$ & $<0.001^{*}$ & $<0.001^{*}$ & $<0.001^{*}$ \\
\hline
\end{tabular}

Table 4: Correlation between the studied parameters in pancreatic tissues

\begin{tabular}{|c|c|c|c|}
\hline \multicolumn{2}{|c|}{} & Tissue TNF- $\alpha$ & Tissue PON-1 \\
\hline \multirow{2}{*}{ Tissue PON-1 } & $\mathbf{r}$ & -0.914 & \multirow{2}{*}{} \\
\cline { 2 - 4 } & P-value & $<0.001^{*}$ & \\
\hline \multirow{2}{*}{ Tissue MPO } & $\mathbf{r}$ & 0.837 & -0.754 \\
\cline { 2 - 4 } & P-value & $<0.001^{*}$ & $<0.001^{*}$ \\
\hline
\end{tabular}

Table 5: Correlation between studied parameters in both serum and tissues.

\begin{tabular}{|c|c|c|c|c|}
\hline \multicolumn{2}{|c|}{ Serum TNF- $\alpha$} & Tissue TNF- & Tissue MPO & Tissue PON1 \\
\cline { 2 - 5 } & P-value & $<0.947$ & & \\
\hline \multirow{2}{*}{ Serum MPO } & $\mathbf{r}$ & & & \\
& P-value & & $<0.904$ & \\
\hline \multirow{2}{*}{ Serum PON-1 } & $\mathbf{r}$ & & & $0.001^{*}$ \\
\cline { 2 - 5 } & P-value & & & $<0.001^{*}$ \\
\hline
\end{tabular}




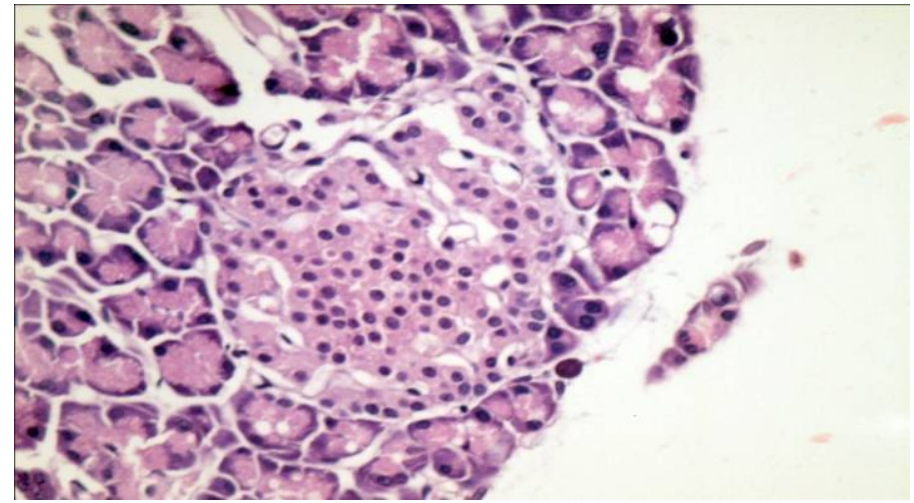

Fig 1: Section of the pancreas from group I (Hx. \&E. X 200).

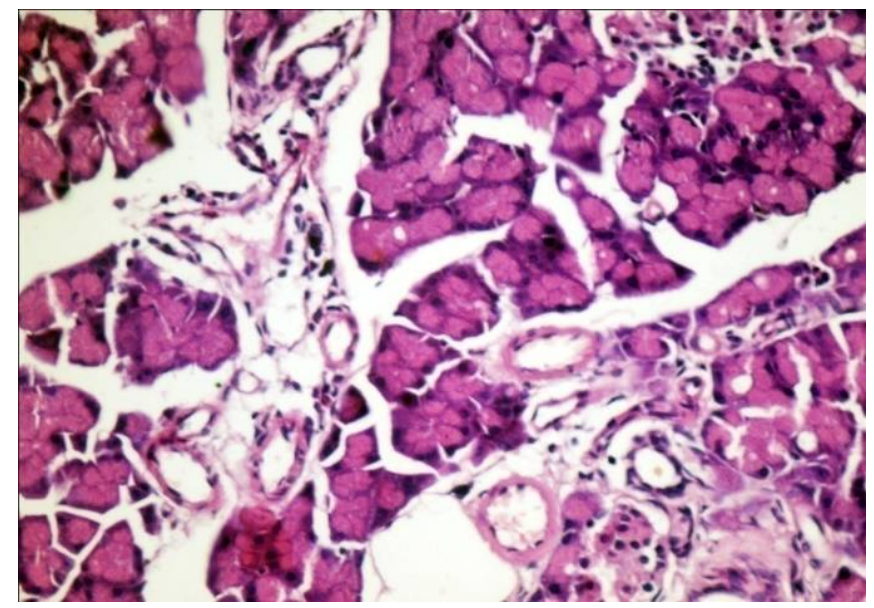

Fig 2: Section of the pancreas from group II (Hx. \&E. X 200).

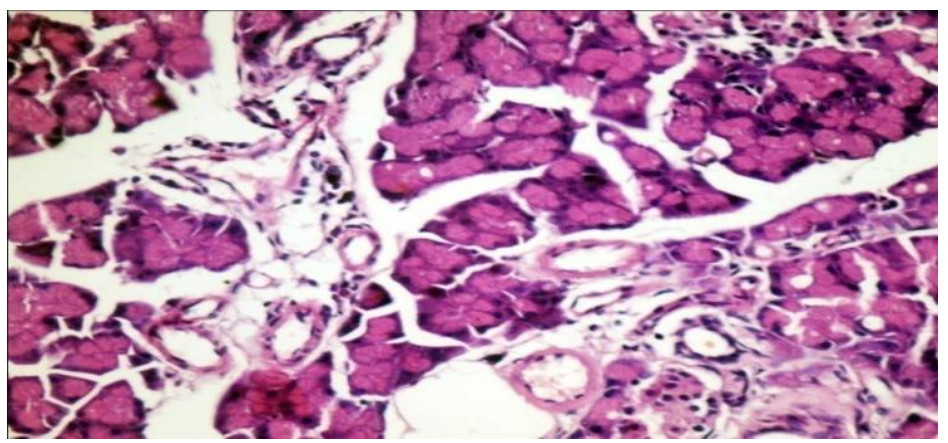

Fig 3: Section of the pancreas from group III (Hx. \&E. X 200). 


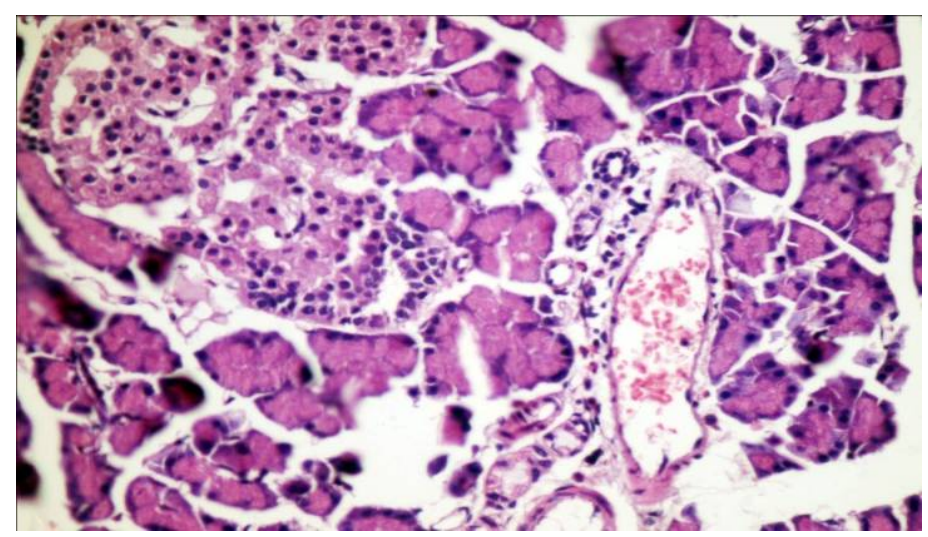

Fig. 4. : Section of the pancreas from group IV (Hx. \&E. X 200).

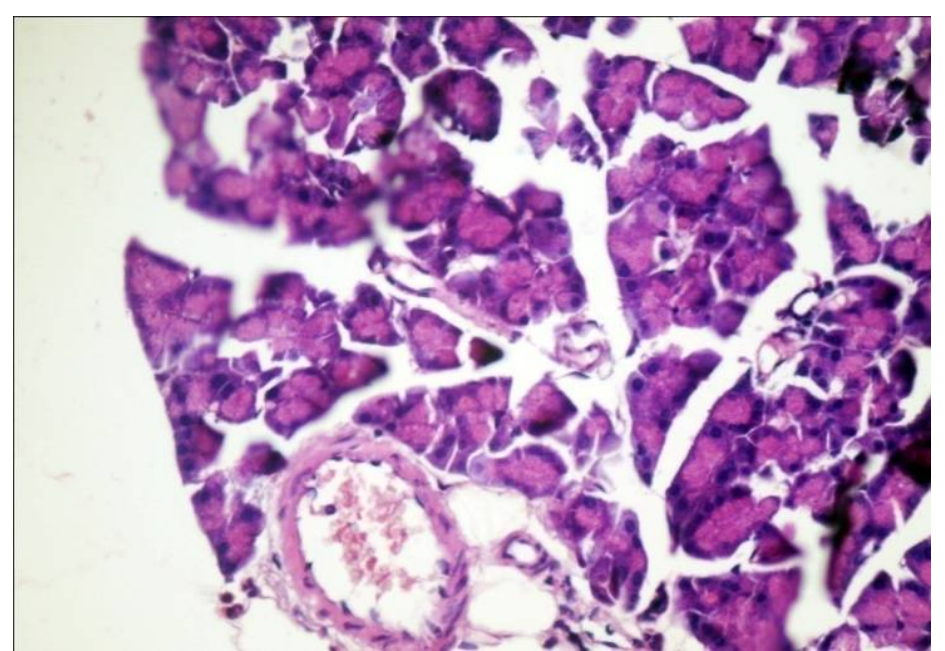

Fig. 5: Section of the pancreas from group V (Hx. \&E. X 200).

\section{DISCUSSION}

Both experimental and clinical evidences have shown that proinflammatory cytokines and oxidative stress are critically involved in the development of local and systemic complications associated with acute pancreatitis ${ }^{(23)}$.

Melatonin has received considerable attention because of its anti-oxidative

property ${ }^{(24)}$. Accordingly, the present study was designed to investigate the effects of melatonin pre- and post-treatment with L-arginine (L-Arg.) on some inflammatory markers in acute pancreatitis in rats.

Our data showed significant increases of both serum amylase and lipase activities in L-arginine injected group. Significant decrease of their 
activities was detected in melatonin injected groups. These results are in agreement with the results of Matull et al. ${ }^{\text {(25) }}$ who reported an increase of serum amylase and lipase enzyme activities in acute pancreatitis confirming their diagnostic roles ${ }^{(25)}$. This increase may be due to the excessive production of ROS by activated leukocytes and acinar cells together with a decreased capacity of intrinsic anti-oxidative defense system leading to peroxidation of lipid membranes and disintegration of the cytoskeleton. This disturbs the intracellular transport of lysosomal and digestive enzymes, causing their premature activation, auto-digestion and cell death ${ }^{(25,26)}$.

The decreased serum amylase and lipase activities with melatonin injection may be due to the effective role of melatonin in decreasing pancreatic damage caused by ROS during AP by restoring the fine structure of acinar cells and restoring tissue antioxidant enzyme activities. Also, melatonin has unique role in its ability to protect various tissues against the damage caused by $\operatorname{ROS}^{(27)}$.

Several research lines have suggested that TNF- $\alpha$ plays a pivotal role in the pathogenesis of different autoimmune and inflammatory diseases including acute pancreatitis $^{(\mathbf{2 8 )}}$. It is a key regulator of other pro-inflammatory cytokines and of leukocyte adhesion molecules and it is a priming activator of immune cells $^{(29)}$.

The important influence of TNF$\alpha$ on microcirculatory disturbance in AP may be mediated through the upregulation of the effect of Intercellular adhesion molecule I (ICAM I) on vascular endothelial cells, promotion of leukocyte adhesion, and increased capillary permeability and plasma extravasation. Also, the downregulation of the expression of thrombomodulin in endothelial cells, activation of the coagulation system, and promotion of microcirculatory stagnation and thrombosis; and direct impairment of vascular endothelial cells, which significantly increases pancreatic capillary permeability ${ }^{(30)}$.

Our study showed significant increase of both serum and pancreatic tissue TNF- $\alpha$ levels in L-arginine injected group. Significant decrease of their levels in melatonin injected groups either pre- or post-L-arginine injection (group III and group IV) with the lowest levels group III.

These results are in harmony with other previous studies that documented an increased blood TNF$\alpha$ and its soluble receptors concentrations in rat models of acute edematous pancreatitis and acute necrotizing pancreatitis ${ }^{(29,31)}$. Also, an increased TNF- $\alpha$ in the serum of patients with acute pancreatitis has been reported and these levels appear to be correlated with the severity of pancreatic inflammation ${ }^{(32)}$.

Su et al. ${ }^{(33)}$ found an increase in TNF- $\alpha$ protein level in the pancreatic tissue of experimentally induced pancreatitis in rats than those of the control group. They suggested that TNF- $\alpha$ is a pivotal factor in pathogenesis of pancreatitis, it cooperates with amylase and lipase to intensify the leisure in pancreatic tissue resulting in bleeding and necrosis ${ }^{(33)}$. It has been reported that the overproduction of TNF- $\alpha$ in acute pancreatitis is pivotal in the induction 
of inflammatory genes, cell death, endothelial up-regulation, and in the recruitment and activation of immune cells and it is regarded as one of the major mediators of systemic progression and tissue damage in severe form of the disease ${ }^{(34)}$.

The results of the current study also confirm the notion that melatonin is capable of reducing elevated TNF- $\alpha$ concentrations in acute pancreatitis. These results are in agreement with those of Gülben et al. ${ }^{(35)}$ who concluded that exogenous melatonin, and that produced from L-tryptophan, attenuates pancreatic damage in rats with acute pancreatitis and such effect could be attributed to the reduction in oxidative stress, damaging effects and TNF- $\alpha$ release ${ }^{(35)}$.

Melatonin could limit the propagation of the inflammatory process and in this way could reduce pancreatic tissue damage. Also, melatonin-induced protection of the pancreas depends not only on the antioxidative effect of that indole, but probably also on its immunemodulatory effect $^{(36)}$. Another possible mechanism of the protective effect of melatonin is that melatonin exerts an anti-inflammatory effect by inhibiting the activation of nuclear

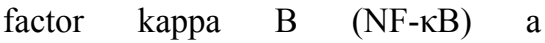
transcription factor with a central role in the development of inflammatory diseases. Blocking the activation of $\mathrm{NF}-\kappa \mathrm{B}$ eliminates the induced overexpression of inflammatory cytokines (TNF- $\alpha$ ) in acute pancreatitis ${ }^{(37)}$.

Oxidative stress and TNF- $\alpha$ seem to potentiate each other, generating a vicious circle in the course of AP. TNF- $\alpha$ intensifies oxidative stress through different mechanisms; conversion of xanthine dehydrogenase to xanthine oxidase $(\mathrm{XO})$ in endothelial cells; increasing the mitochondrial production of ROS, and promoting chemotaxis and activation of neutrophils ${ }^{(38)}$. MPO is one of the enzymes contained in azurophilic granules. Increased MPO blood levels reflect neutrophil activation ${ }^{(9)}$. Derivatives of myeloperoxides oxidation can evoke the liberation of vasoactive amines from platelets and mast cells ${ }^{(39)}$.

Our results showed significant increase of both serum and tissue MPO enzyme activities in L-arginine injected group with significant decrease in their activity in melatonin injected groups (group III and group IV) with the lowest activities in group III. These results are in agreement with those of Chooklin et al. ${ }^{(40)}$ who reported an increased MPO activity in acute pancreatitis patients which was more prominent in severe pancreatitis than in mild pancreatitis ${ }^{(40)}$. They also, showed that prolonged high MPO activity points to continued neutrophil activation with the liberation of biologically active substances (cytokines and ROS) ${ }^{(40)}$.

Okutan et al. ${ }^{(41)}$ and Kaçmaz et al. ${ }^{(42)}$ reported that MPO activity, which is an index of tissue neutrophil infiltration, is inhibited by melatonin treatment, this finding suggests its anti-inflammatory effect. Melatonin also inhibits the generation of free radicals and the accumulation of neutrophils in the damaged tissues. Melatonin's antioxidant action is also derived from its protective effects on antioxidant enzymes ${ }^{\mathbf{4 1}, \mathbf{4 2})}$.

Serum TAC levels were significantly increased in L-arginine 
injected group. Also, significant increase of its level was found in melatonin pre-treatment with Larginine injection (group III). Significantly lower level was found in melatonin injected group after Larginine injection (group IV). Our results are in agreement with the results of Chuang et al. ${ }^{(10)}$ who reported that the increased serum TAC levels in patients with acute pancreatitis reflected clinical severity of sepsis in those patients and serum TAC levels became elevated as APACHE II scores rose ${ }^{(\mathbf{1 0})}$.

Serum and tissue PON1 enzyme activities showed significant decrease in L-arginine injected group, but significant increase in their activities were detected in both melatonin injected groups (group III and group IV), with no significant difference between them. Our results are in agreement with the results of FrancoFranco-Pons et al. ${ }^{(43)}$ and Xing-liang et al. $^{(44)}$ who reported significant decrease in serum PON1 activity during severe acute pancreatitis ${ }^{(43,44)}$.

The observed decrease in serum PON1 activity may be due to several factors including; proteolytic degradation of PON1 by the effect of circulating hydrolytic enzymes released in the early stages of acute pancreatitis, or through oxidative inactivation and modification of the enzyme ${ }^{(43)}$. Also, it could be related to an inhibition in hepatic PON1 synthesis. The latter possibility is related to the fact that liver is the main source of PON1 ${ }^{(45)}$.

On the other hand, it has been reported that during the early stages of acute pancreatitis, a sort of acutephase response occurs resulting in changes in the expression of different proteins in the liver. In addition, during pancreatitis, concentrations of IL-6 increases significantly, and this interleukin acts as inhibitor of liver expression of PON1 ${ }^{(45)}$.

Melatonin seems to function via a number of means to reduce oxidative stress. Experimental evidence supports its actions as a direct free radical scavenger of peroxyl radicals, hydroxyl radicals, and other reactive oxygen species ${ }^{(46)}$. Sahin et al. $^{(47)}$ reported that melatonin has an indirect antioxidant action by stimulating the activity of several enzymes related to the anti-oxidative defense system including the activity of PON and arylesterase ${ }^{(47)}$.

It also, protects the anti-oxidative enzymes from oxidative damage, and increases the efficiency of mitochondrial electron transport chain (ETC), thereby lowering electron leakage and reducing free radical generation $^{(48)}$.

Conclusion: All the above findings might confirm the protective effect of melatonin as an antioxidant in acute pancreatitis.

\section{REFERENCES}

1. Banks P.A. and Freeman M.L. (2006): Practice guidelines in acute pancreatitis. Am. J. Gastroenterol., 101: 2379-2400.

2. Mofidi R., Duff M. D., Wigmore S.J. et al., (2006): Association between early systemic inflammatory response, severity of multi-organ dysfunction and death in acute pancreatitis. Br. J. Surg., 93:738744. 
3. De-Madaria E., Martínez J., Sempere L. et al., (2008): Cytokine genotypes in acute pancreatitis: association with etiology, severity, and cytokine levels in blood. Pancreas 37:295301.

4. Park B.K., Chung J.B., Lee J.H., Suh J.H., Park S.W., Song S.Y., Kim H., Kim K.H. and Kang J.K. (2003): Role of oxygen free radicals in patients with acute pancreatitis. World J Gastroenterol., 9: 2266-2269.

5. Lindström O., Jarva H., Meri S. et al., (2008): Elevated levels of the complement regulator protein CD59 in severe acute pancreatitis. Scand. J. Gastroenterol., 43:350-355.

6. Locksley R. M., Killeen N. and Lenardo M.J. (2001): The TNF and TNF receptor super-families: integrating mammalian biology Cell., 104: 487-501.

7. Dale D.C., Boxer L. and Liles W. C (2008): The phagocytes: neutrophils and monocytes. Blood., 112:935-945.

8. Nauseef W. M. (2001): Contributions of myeloperoxidase to pro-inflammatory events: more than an antimicrobial system. Int. J. Hematol., 74:125-133.

9. Stefanescu A, Braun S., Ndrepepa G, et al., (2008): Prognostic value of plasma myeloperoxidase concentration in patients with stable coronary artery disease. Am. Heart J., 155:356-360.

10. Chuang C., Shiesh S., Chi C. et al., (2006): Serum total antioxidant capacity reflects severity of illness in patients with severe sepsis. Critical Care Med., 30:1782-1786.

11. Deakin S., Leviev I., Meynet B.M.C. et al., (2003): PON1 promoter haplotypes and serum PON: a predominant role in vivo for polymorphic position -107 implicating the transcript factor SP1. Biochem J., 372: 643-649.

12. Reddy S.T., Wadleigh D. J., Grijalva V. et al., (2001): Human paraoxonase-3 is an HDL-associated enzyme with biological activity similar to paraoxonase-1 protein but is not regulated by oxidized lipids. Arterioscler. Thromb. Vasc. Biol., 21: 542-547.

13. Allegra M., Reiter R.S., Tan D.X. et al., (2003): The chemistry of melatonin's interaction with reactive species. J. Pineal Res., 34: 1-10.

14. Rodriguez C., Mayo J.C., Sainz R. M. et al., (2004): Regulation of oxidative enzymes; a significant role for melatonin. J Pineal Res., 36: 1-9.

15. Szaboles A., Reiter R. J., Letoha T. et al., (2006): Effect of melatonin on the severity of Larginine-induced experimental acute pancreatitis in rats. World J. Gastroenterol., 812:251-258.

16. Rauscher E., Neumann U., Schaich E. et al., (1985): Optimized conditions for determining activity concentration of $\alpha$ amylase in serum with $1,4 \quad \alpha$-D-4 nitrophenylmaltoheptaoside as substrate. Clin. Chem., 31:31:14.

17. Lott J.A., Patel S.T., Sawhney A.K. et al., (1986): Assays of serum lipase: Analytical and 
clinical considerations. Clin. Chem., 32:1290-1302.

18. Koracevic D., Koracevic G. and Djordjevic V. (2001): Method for the measurement of antioxidant activity in human fluids J. Clin. Pthol., 54: 356-361.

19. Martinez V., Mitjans M. and Vinardell M.P. (2004): TNF $\alpha$ measurement in rat and human whole blood as an In vitro method to assay pyrogens and its inhibition by dexamethasone and erythromycin. Journal of pharmaceutical sciences. 93:2718-2723.

20. Kuebler W.M., Abels C., Schuerer L. et al., (1996): Measurement of neutrophil content in brain and lung tissue by a modified myeloperoxidase assay. Int. J. Microcirc. Clin. Exp., 16:89-97.

21. McEIveen J., Macknees M.I., CoVey M. et al., (1986): Distribution of paraoxon hydrolytic activity in the serum of patients after myocardial infarction. Clin. Chem., 32: 671673.

22. Lowry O.H., Rosebrough N.J., Farr A.L. et al., (1951): Protein measurement with the Folin phenol reagent. J. Biol. Chem., 193: 265-275.

23. Gomez-Cambronero

L.G., Sabater L., Pereda J. et al., (2002): Role of cytokines and oxidative stress in the pathophysiology of acute pancreatitis: Therapeutical implications. Current Drug Targets Inflammation \& Allergy. 4:393-403.
24. Suzen S. (2006): Recent developments of melatonin related antioxidant compounds. Comb Chem. High Throughtput Screen. 9:409-419.

25. Matull W.R., Pereira S.P. and O'Donohue J.W. (2006): Biochemical markers of acute pancreatitis. J. Clin. Pathol., 59: 340-344.

26. Esrefog M. N., Gui M., Ates B. et al., (2006): Anti-oxidative effect of melatonin, ascorbic acid and $\mathrm{N}$-acetylcysteine on caerulein-induced pancreatitis and associated liver injury in rats World J Gastroenterol., 12:259-264.

27. Cöl C., Dinler K., Hasdemir A.O. et al., (2009): The effect of an intra-peritoneal injection of melatonin on serum amylase levels in acute pancreatitis. J. Pancreas 10:306-309.

28. Cöl C., Dinler K. and Hasdemir A.O (2010): Exogenous melatonin treatment reduces hepatocyte damage in rats with experimental acute pancreatitis. J. Hepatobiliary Pancreat. Sci., 17:682-687.

29. Malleo G., Mazzon E., Siriwardena A.K. et al., (2007): Role of tumor necrosis factoralpha in acute pancreatitis: from biological basis to clinical evidence. Shock 28:130-140.

30. Takeda K. (2004): Role of tumor necrosis factor-alpha in increase permeability and circulatory failure in the development of organ dysfunction in severe acute pancreatitis. Nippon Rinsho., 62:1999-2004. 
31. Granell S., Pereda J., Luis G. et al., (2003): Circulating TNF- $\alpha$ and its soluble receptors during experimental acute pancreatitis. Cytokine 5:187-191.

32. Majer J., Rau B., Gansauge F. and Beger H.G. (2000): Inflammatory mediators in human acute pancreatitis: clinical and pathophysiological implications. Gut 47:546-552.

33. Su J.R., Zhao Z.C., Chen W.L. et al., (2003): The effect of activated nuclear factor kappa B in pathogenesis of acute pancreatitis. Dig. Dis. Sci., 83:1497-1500.

34. Bhatia M., Wong F.L., Cao Y., Lau H.Y., Huang J., Puneet P. and Chevali L. (2005): Pathophysiology of acute pancreatitis. Pancreatology 5:132-144.

35. Gülben K., Ozdemir H. and Berberoğlu U. (2010): Melatonin modulates the severity of taurocholate-induced acute pancreatitis in the rat. Dig Dis Sci., 55:941-946.

36. Jaworek J., Nawrot K., Konturek S.J. et al., (2004): Melatonin and its precursor; Ltryptophan: influence on pancreatic amylase secretion in vivo and in vitro. J. Pineal Res., 36: 156-164.

37. Rakonczay Z., Hegyi P., Takács T. et al., (2008): The role of NF- $\kappa B$ activation in the pathogenesis of acute pancreatitis Gut 57:259-267.

38. Pereda J., Sabater L., Cassinello N., GómezCambronero L. et al., (2004): Effect of simultaneous inhibition of TNF- $\alpha$ production and xanthine oxidase in experimental acute pancreatitis. The role of mitogen activated protein kinases. Ann Surg. 2004 July; 240(1): 108-116.

39. El Kebir D., József L., Pan W. et al., (2008): Myeloperoxidase delays neutrophil apoptosis through $\mathrm{CD} 11 \mathrm{~b} / \mathrm{CD} 18$ integrins and prolongs inflammation. Circ. Res., 103:352-359.

40. Chooklin S., Pereyaslov A. and Bihalskyy I. (2009): Pathogenic role of myeloperoxidase in acute pancreatitis. Hepatobiliary Pancreat. Dis Int., 8: 627-631.

41. Okutan H., Savas C. and Delibas K. (2004): The antioxidant effect of melatonin in lung injury after aortic occlusionreperfusion. Interactive Cardiovascular and Thoracic Surgery 3:519-522.

42. Kaçmaz A., User E., Sehirli O. et al., (2005): Protective effect of melatonin against Ischemia/reperfusion-Induced oxidative remote organ Injury in the rat. Surg. Today .35:744-750.

43. Franco-Pons N., Marsillach J., Joven J. et al., (2008): Serum paraoxonase undergoes inhibition and proteolysis during experimental acute pancreatitis. J. Gastrointest. Surg., 12:891-899.

44. Xing-liang J., Qu-ming F., Xiao-lan Z. et al., (2010): Plasma paraoxonase- 1 activity in patients with acute pancreatitis and its clinical significance. China Journal of Modern Medicine.4:154-160.

45. Folch-Puy E. (2007): Importance of the liver in systemic 
complications associated with acute pancreatitis: the role of Kupffer cells. J Pathol., 211:383388.

46. Reiter R.J., Tan D., Mayo J.C. et al., (2003): Melatonin as an antioxidant: biochemical mechanisms and pathophysiological implications in humans. Acta biochemical Polonica 50:1129-1146.

47. Sahin K., Onderci M. and Gursu M.F. (2004): Effect of
Melatonin supplementation on biomarkers of oxidative stress and serum vitamin and mineral concentrations in heat-stressed Japanese. Quail J. Appl. Poult. Res., 13:342-348.

48. Mayo J.C., Tan D.X., Sainz R.M. et al., (2003): Oxidative damage to catalase induced by peroxyl radicals: Functional protection by melatonin and other antioxidants. Free Radic Res., 37: 543-53. 


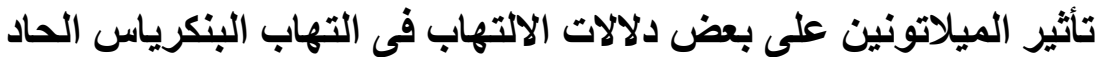

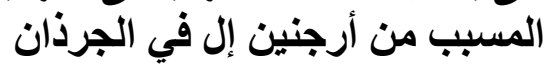

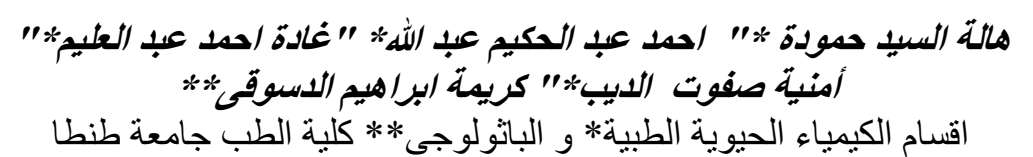

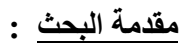

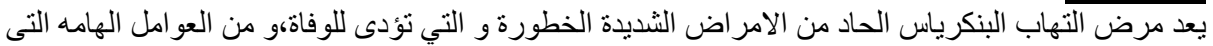

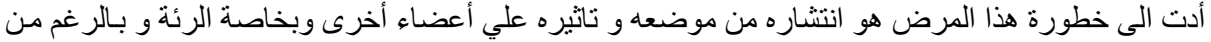

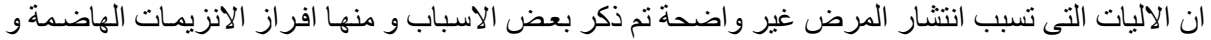

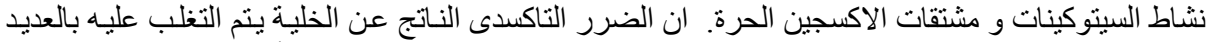

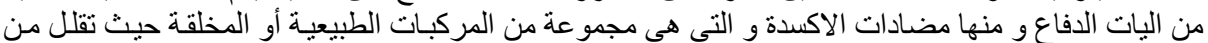

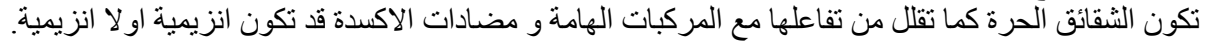

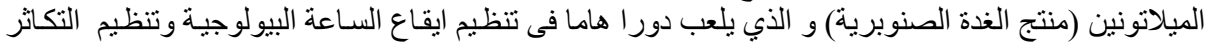

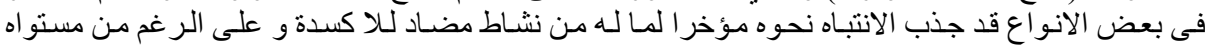

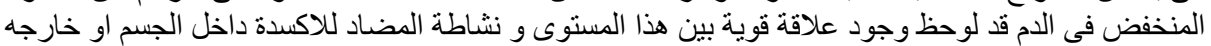

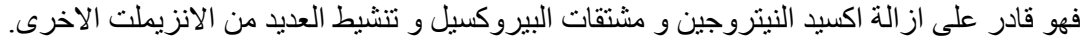

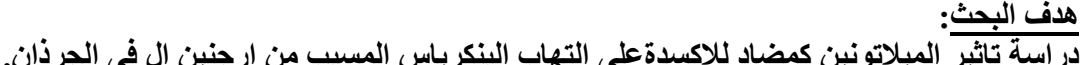

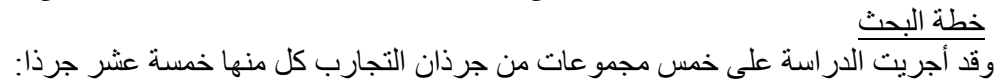

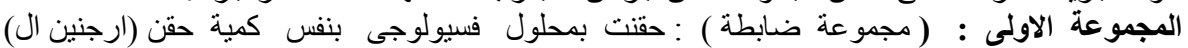

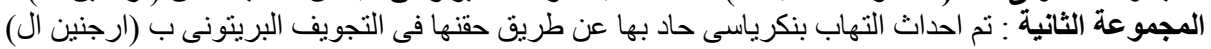

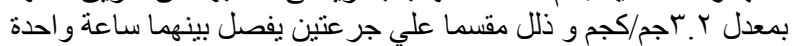

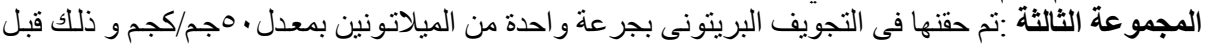

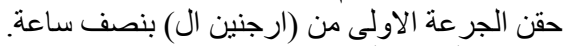

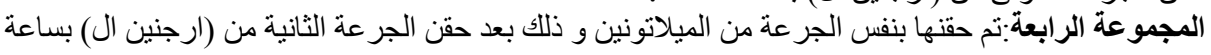
واحدة. المجموعة الخامسة: تلقت جرعة واحة واحدة من الميلاتونين. و كل هذة المجمو عات تم فيها القياسات الاتية:

ـ قياس نشاط مضادات الاكسدة ـ تقدير نشاط انزيم البار الوكسينيز

-تقدير نشاط انزيم البار الوكسينيز ــ في المصل: ـ تقدير نشاط انزيم المايلوبيروكسيديز.

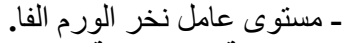
فحى الانسجة البنكرياسية:

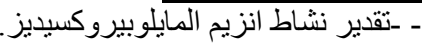

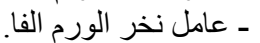
ونم أخذ عينات من بنكرياس كل مجمو عات الدر اسة للفحص الهُنتوباثولوجى

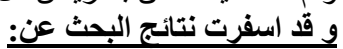

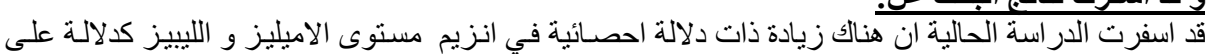

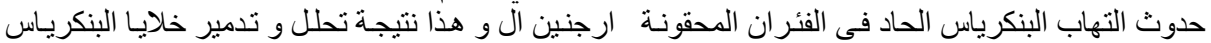
نتيجة افراز انواع الاكسجين التفاعلية. 


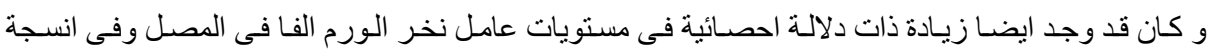

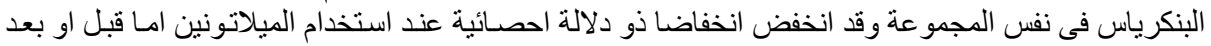

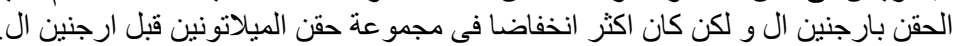

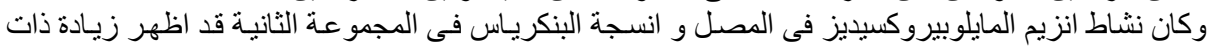

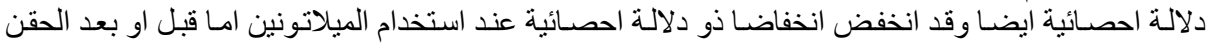

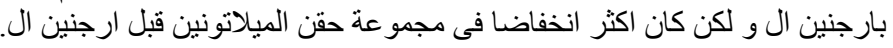

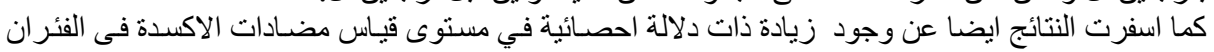

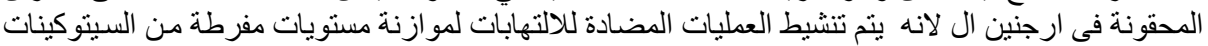

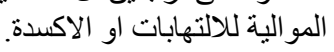

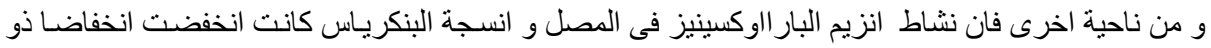

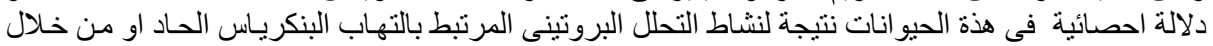

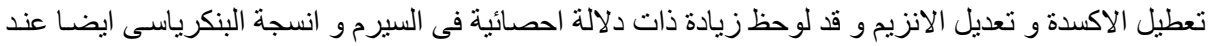

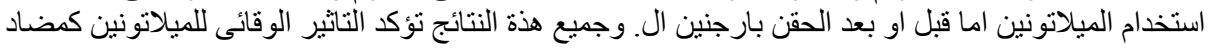

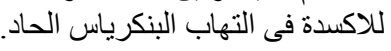

